\title{
STUDY OF THE AURIGNACIAN-GRAVETTIAN «TRANSITION» EAST OF THE CARPATHIANS: BLADELET PRODUCTION FEATURES FROM MITOC-MALU GALBEN (ROMANIA) AND MOLODOVA V (UKRAINE)
}

\begin{abstract}
Although the Aurignacian to Gravettian "transition" represents a considerable cultural change, this issue still lacks an explanatory consensus and needs further researches. Data is quite unequal throughout Europe, as exemplified by the middle Prut and Dniestr area, which have remained little investigated so far, despite the presence of different sites related to Late Aurignacian and Early Gravettian. Some of these sites consist of secure sequences with high-resolution climatic context and abundant archaeology, such as Molodova V(Ukraine) or Mitoc-Malu Galben (Romania). Rich in lithic artefacts, these collections have rarely been examined else than typologically. In order to highlight this phenomenon in the concerned area, we have studied and confronted the bladelet production patterns from Mitoc-Malu Galben's Late Aurignacian to Molodova V's Early Gravettian. Preliminary results emphasize the technological individuality of both technocomplexes, but further investigations on materials and contextual data are necessary to confirm any population dynamics model.
\end{abstract}

Keywords: Bladelet production, Lithic technology, Aurignacian, Gravettian, Eastern Europe.

Introduction. Aurignacian and Gravettian both represent major well-defined Upper Palaeolithic cultures, associated to several respective specificities justifying their uniformity over time and space. It is consensually accepted that the appearance of the Aurignacian in Europe, before $40000 \mathrm{BP}$, is connected to the movements of Homo Sapiens (Hublin 2015; Nigst et al. 2014); despite some evolution, its material features stood stable enough to consider it a consistent cultural entity for more than 10000 years (eds. Bar-Yosef, Zilhro 2006; eds. Zilhro, d’Errico 2003; Kozłowski, Otte 2000). Starting from 30000 BP approximately, the cultural landscape changes with the first occurrences of the Gravettian. New behaviours and material features attest to this change (ed. Gou- tas et al. 2011; ed. Otte 2013), while its material general characteristics relate to the Upper Palaeolithic just as the Aurignacian.

The nature of this shift is still debated (Kozłowski 2015). On one hand, a simultaneity model stems from the observation that several early Gravettian sites throughout Europe bear dates reaching as far as 27000-28000 BP. Facing such facts, a general adaptative interpretation is relevant. But, on another hand, a monocentric model is also seriously considered, if not dominating. Based on the idea that Gravettian «innovations» have first appeared in a specific area, such a model emphasizes the importance of population movements or cultural diffusion. In this perspective, Central Europe is usually regarded as the most probable primary centre (Otte, Noiret 2004), with dates for the Gravettian going over $29000 \mathrm{BP}$, or maybe $30000 \mathrm{BP}$ with less confidence (Haesaerts et al. 1996, Kozłowski 2015). An inflexible point of view should preferably be left aside while considering those hypotheses, as both are defendable, and as several factors are probably involved. Insights from genetics, although preliminary, have suggested a real but unequal impact of population movements and replacements (Fu et al. 2016), strengthening this assertion. Facing a continent-scaled phenomenon, regionally differentiated explanations are, to say the least, cautiously justified.

Concerning this issue, Eastern Europe is also involved, even though the situation is unclear and complexified by the recognition of other cultural entities (e. g. Streletskian, Gorodtsovian) in the same time slot (Sinitsyn 2015). Specifically, the area encompassing the middle Prut and middle Dniestr basins is no exception. Both cultural entities are present there, but chronologies often 
lack precision (Noiret 2009). Indeed, assured $\mathrm{Au}$ rignacian sequences are scarce and often approximately set chronologically. If sites further East such as Kostienki 1/III (Sinitsyn 1993, 2015), Kostienki 14/LVA (Sinitsyn 2003, 2015) or Siuren I (eds. Demidenko et al. 2012) support the recognition as Aurignacian, in the whole Moldavian area Mitoc-Malu Galben stands as the only reliable occurrence. The site of Corpaci-MBs, also on the Prut river, might be the only other Aurignacian instance, but published data do not allow to go over uncertainties in dates and attributions of this assemblage (Noiret 2004; 2009). Despite this bad representation, the data suggests that an archaeological bias, e. g. representativity or recognition, could be considered explanatorily; a functional bias has also been proposed (Hoffecker 2011; Hoffecker et al. 2018). The picture is different for the Gravettian, as instances related to this wide technocomplex are numerous (Noiret 2007; 2009). The early occurrences, however, are almost exclusive to the Molodova $\mathrm{V}$ sequence, which stands as a cornerstone in the local model. Its early Gravettian horizons (labelled 10 and 9) reach $29000 \mathrm{BP}$ or even earlier for level 10 (Haesaerts et al. 2003). Unfortunately, published materials and associated data are often limited to typological approaches, unfit to characterize such phenomenon, and requiring new investigations.

Material and methods. In the lithic domain, Aurignacian and Gravettian materials logically show common features, both being Upper Palaeolithic cultures. Indeed, despite the developments of technological approaches, the distinction between both technocomplexes still partly relies on the recognition of typological features to assess with certainty. Nevertheless, distinctive technological features are a reality, even though they are often subject to variability, due to the wideness of these entities and the impacts of non-cultural constraints. This said, the bladelet production domain is quite differentiated between both technocomplexes. More especially, the Aurignacian bladelet production is often considered to bear particular technological features, already crystallized under different typological forms (e. g. carinated burin and endscraper) for decades (ed. Le Brun-Ricalens et al. 2005; Le Brun-Ricalens 2005). Concerning the Gravettian bladelet technology, focus was often set on the products themselves, highlighting more peculiarities than general characteristics (Pesesse 2013). Still, the observation of Gravettian blanks' straightness and lightness is usually accepted. Finally, an additional reason to investigate on bladelet productions before other aspects comes from their uses, frequently related to the projectile point domain. That kind of artefacts being highly typologized, their related technologies also have the potential to act as proxies in such an issue.

In the frame of this study, all artefacts related to bladelet production have then been examined following a technological approach, including reduction sequence reconstruction, refits and attribute analysis; however, hereinafter presented data is mostly qualitative. Studied materials comprise primary and secondary bladelets, all associated maintenance blanks, and cores.

Focusing on the Prut and Dniestr area, attention was set on the most reliable and relevant sequences to acquire data: Mitoc-Malu Galben (MMG; Romania) and Molodova V (Ukraine).

MMG is one of the Upper Palaeolithic key-sites of Romania. Situated on the North-Eastern border of the country, along the river Prut, it consists of a $14 \mathrm{~m}$ high loess sequence, with multiple $\mathrm{Au}$ rignacian and Gravettian horizons (ed. Otte et al. 2007a). The modern archaeological investigations took place almost continuously from 1978 to 1995 (ed. Otte et al. 2007a), and from 2013 to 2016 (Libois et al. 2018; Noiret et al. 2016). Human occupations are divided in five Aurignacian and five Gravettian concentrations, labelled numerically from bottom to top ("Aurignacian I», «II», «III», «III Supérieur»; Gravettian «I», «II», «III», «IV»); lowermost and uppermost layers are respectively labelled "Aurignacian Inférieur» and «Gravettian Indifférencié». A large radiocarbon dating campaign led in a stratigraphically controlled environment allowed to precisely and consistently set all archaeological horizons (Haesaerts 2007). In MMG, the Aurignacian spans then from 33000 to $27500 \mathrm{BP}$, while the main Gravettian occupations are set in the 27000-23000 BP time slot. Particularly, the first consistent horizon, "Aurignacian I», is dated around $31000 \mathrm{BP}$, while later Aurignacian levels, "III» and «III Supérieur», are respectively dated from around $29500 \mathrm{BP}$ and at 27500 BP. Materials originating from the 19781990 excavations were unfortunately subjected to selection; especially tools, cores, and some primary blanks were preserved. Later excavations happily provided with complete assemblages, still mostly unsieved in the $1990^{\mathrm{s}}$ (Noiret 2005, p. 448).

From this site, two representative complete samples were taken into account for this study, coming from horizons "Aurignacian I» and «III». Moreover, further details from «Aurignacian III Supérieur» level were obtained by examining tools and cores from the older phase of excavation (1978-1990). In the frame of this project, no Gravettian bladelet assemblages from MMG have not been examined yet. The chosen "Aurignacian I» sample corresponds to the lithic remains associated to a hearth sampled in squares L5L 6 by the Belgian team in the $1990^{\text {s }}$ (Noiret et al. 2006). The considered "Aurignacian III" assemblage originates from the 1990 excavation. Limited to squares F03 and G03, this is one of the only complete assemblages of the 1978-1990 phase of excavations.

On the other hand, collections from the renowned site of Molodova V were partly studied. 
Situated in South-Western Ukraine, in the middle Dniestr basin, this $25 \mathrm{~m}$ high multi-layered sequence was excavated from 1951 to 1964 (eds. Ivanova, Tzeitlin 1987). It encompasses numerous Middle and Upper Palaeolithic horizons, mostly related to Mousterian, Gravettian, Epigravettian and Mesolithic; layers 10 and 9 are the first Gravettian ones. The sequence was chronologically set with rather good precision by the excavating team (Ivanova 1987); later, a revision campaign also deepened the absolute chronology resolution (Haesaerts et al. 2003, Haesaerts 2007). Even though layer 10 isn't precisely dated, layer 9 is radiocarbon dated at the latest around $29000 \mathrm{BP}$. As far as known, fieldwork didn't include sieving, but all materials were kept after excavation; so far, storage issues only are incriminated for the loss of materials.

Most of the materials related to archaeological horizons 10 and 9 were excavated in 1953 and 1954. A limited number of pieces comes from years 1955, 1960 and 1962; for a question of assemblage consistency, those were not taken into account in this frame. Layer 10 is complete at about $70 \%$ in comparison to the published counts (Chernysh 1987). Unfortunately, missing materials include part of the tools and most of the blades and bladelets. Bladelet production details were then inferred from cores and a limited number of products. Spatial analysis, based on markings, has revealed two main clusters of artefacts; due to their high representativity in bladelet production related artefacts, pieces from cluster 2 only were included in this study (squares 12 to 14, and E to K). Layer 9 presents less lacks, as almost $90 \%$ of the materials were recovered; there doesn't seem to be any strong biases in artefacts classes frequencies. No spatial-based selection was applied in the frame of this study to layer 9 materials.

Results. Aurignacian bladelet production schemes are pretty-well illustrated by results from the complete samples examined in MMG's «Aurignacian I» and «III» levels. The «Aurignacian I» level was already well documented, as it is one of the most prolific in the MMG sequence. The older phase of excavations had already assured with the existence of some bladelet production in this level through the presence of numerous carinated tools and associated typological forms (Otte et al. 2007b). Only the detailed goals of the production remain unknown, still now, due to the lack of retouched bladelets from any phase of the excavations. Nevertheless, the L5-L6 sample gives new information on the progression and characteristics of the bladelet production, based on almost 200 bladelet elements and several related products. Among noticeable features is the high proportion of twisted shaped bladelets and naturally pointed ones (fig. 1: 1); most of these blanks do not result from shaping or maintenance phases but from main production. Some maintenance products are also clearly identifiable, as narrow tablets (fig. 1: 2) and lateral maintenance flakes (fig. 1: 3), the latter displaying lateralized bladelet removals on their dorsal surfaces. Those elements attest the narrowness of cores and lateral accentuation of convexities during production. Four sets of refits were reconstructed and support this scheme. More especially, sets 1 and 2 demonstrate the imbrication of varied-sized bladelets. Set 1 proves the narrowing through massive lateral removals (fig. 1: 4), while set 2 clearly shows the symmetric and semi-rotating progression of production (fig. 1:5). All those features can clearly be compared to "classic» carinated tools / cores production (ed. Le Brun-Ricalens et al. 2005, Le Brun-Ricalens 2005).

Contrarily to level «I», the bladelet production from "Aurignacian III" horizon had never been deeply documented. Rich of about 60 bladelets and 12 cores, the F03-G03 assemblage is exceptionally well conserved for this level. Variability in bladelet sizes and shapes is important, as this set includes equally main and side products, as well as initialisation blanks (fig. 1: 6); still, twisted profiles are dominating. Several refit series could be realised on bladelets. Set 1 illustrates the succession of heavily twisted blanks enveloping the production surface (fig. 1: 7). Set 2 shows the removal of a hinged scar followed by two curved and twisted bladelets (fig. 1: 8). As well, the refitting of some products on a core demonstrates pretty well the progression of knapping on the side part of the core, to maintain the lateral convexity (fig. 1: 9). In a general way, other cores from this sample express the same tendencies, expressing again a convergence of lateral and frontal surfaces (fig. 2: 1, 2), feature at the roots of the bladelets' shapes.

Concerning the last Aurignacian horizon in MMG, "Aurignacian III Supérieur», data is regrettably limited to the few carinated tools / cores from the first phase of excavations. Unlike level «III», it reveals changes in proportions and progression of knapping, as narrowing is less intense and production surfaces shorter (fig. 2: 3, 4); a decrease of twisted shapes is expected for produced blanks. Despite these modalities' modifications, the general scheme of production still corresponds to the Aurignacian; yet it is difficult to extrapolate the transformations' conditions due to the paucity of materials.

Regarding Molodova V/10s bladelet production, detailed data comes only from two classes of artefacts: retouched bladelets and cores; no other artefacts could bring substantial information. Retouched bladelets consist of four elements, of diverse raw materials (fig. 2: 5). If complete elements are standardized a bit over $30 \mathrm{~mm}$, width and thickness are more varied. The importance of the back depends on blank's original width, as lighter blanks are less intensively retouched. Bladelets are straight or, at the most, barely curved. Data from cores is consistent with those 

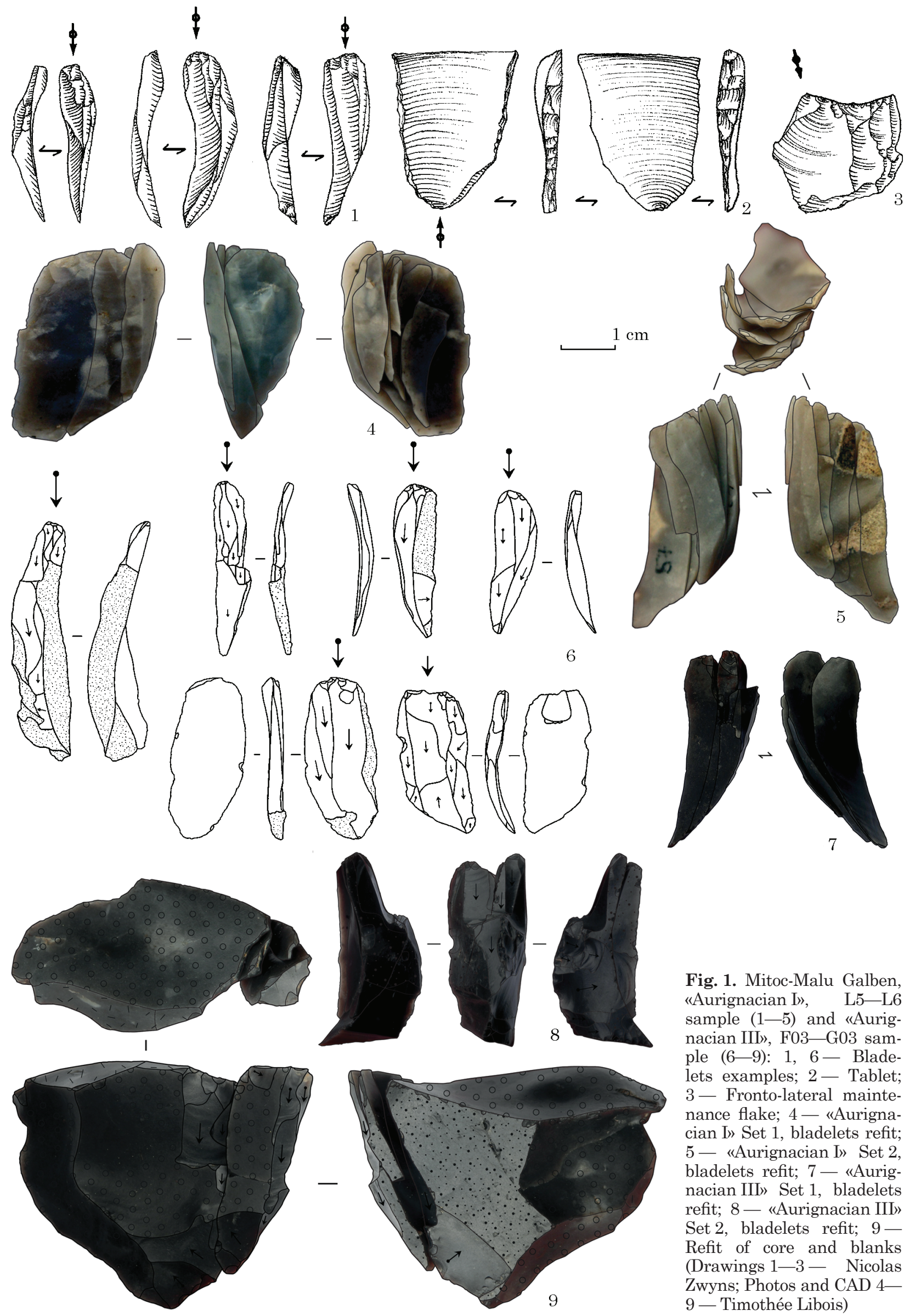

Fig. 1. Mitoc-Malu Galben, "Aurignacian I», L5-L6 sample $(1-5)$ and «Aurignacian III», F03-G03 sample (6-9): 1, 6- Bladelets examples; 2 - Tablet; 3 - Fronto-lateral maintenance flake; 4 - "Aurignacian I» Set 1, bladelets refit; 5 - «Aurignacian I» Set 2, bladelets refit; 7 - «Aurignacian III» Set 1, bladelets refit; 8 - "Aurignacian III» Set 2, bladelets refit; 9 Refit of core and blanks (Drawings 1-3 - Nicolas Zwyns; Photos and CAD 49 - Timothée Libois) 


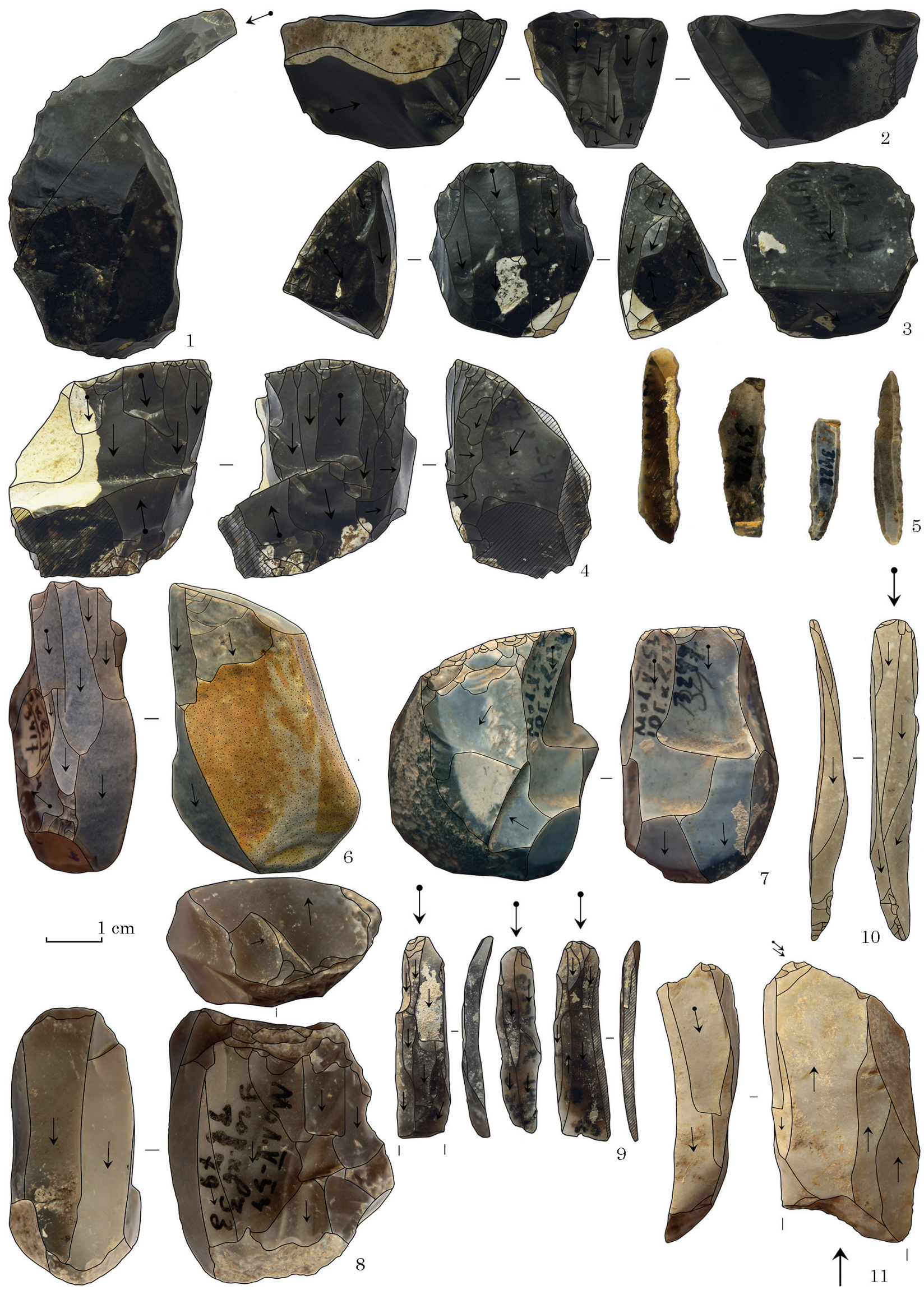

Fig. 2. Mitoc-Malu Galben, «Aurignacian III», F03-G03 sample (1, 2), «Aurignacian III Supérieur» (3, 4), Molodova V, cultural horizon 10 (5-7) and Molodova V, cultural horizon 9 (8-11): 1 - Refit of «carinated burin» and «burin spall»; 2-4, 6-8- Bladelet cores; 5 - Backed bladelets; 9 - Bladelets examples; 10 - Burin spall; 11 - Dihedral / Multiple burin-core (Photos and CAD 1-11 - Timothée Libois) 
end products. Production is predominantly unipolar and knapping surfaces are mostly flat or slightly curved (fig. 2: 6, 7). Raw materials were especially chosen for their natural volumes and proportions, characterized by parallel sides and original thin sections. Expected blanks should then be rather straight medium to big sized bladelets. A «carinated endscraper» is often reproduced from Chernysh's work when mentioning this layer (Chernysh 1987, p. 28, fig. 15). Although this specific piece could not be retrieved in collection, it can easily be compared to the other cores, as many are set the same way on small sized pebbles; the "carinated» assessment seems exaggerated, as this piece is probably one core among the others. Additionally, no Aurignacian related artefacts, especially in the bladelet sphere, could be found, refuting any hypothesis of mixings with Aurignacian materials.

On the contrary, cultural layer 9 shows abundant remains of unretouched bladelets and a few cores. Blanks' variability in size is important; the lack of microbladelets is probably due to excavation methods. Profiles are dominated by straight and slightly curved blanks, with parallel sides, while distal terminations are varied (fig. 2: 9). The twelve bladelet cores are mostly unipolar, although some are exploited from two independent platforms (fig. 2: 8). Production doesn't take place on large faces, but several pieces demonstrate the use of less narrowed blocs than in level 10 . Still, cores are not subject to distal convergence, with prevailing squared sections. Additionally, a specific reduction modality based on burin-like technologies is supposed to produce small blades and bladelets, as exemplified by the presence of burins multiple (fig. 2: 11). Some straight blanks can be connected to it (fig. 2: 10).

Discussion. The origin of the Gravettian East of the Carpathians has already been discussed by several researchers, but proposed models usually have aimed at finding relationships with earlier cultural entities. Limited by the available data, they could only count on typological descriptions and few reliable absolute dates. It is in such a context that unknown transitional industries or even the Szeletian (Anikovich 1992) were suggested as origins of the Gravettian. At last, the internationalisation of results from MMG allowed to consider the Aurignacian a relevant predecessor to the Gravettian in the Prut and Dniestr area (Borziak, Koulakovska 1998).

The Aurignacian presence in MMG was already well assured by former studies, but these new detailed results contribute to several issues. It appears that bladelet production modalities from horizons "Aurignacian I» and "III» are in details comparable to what is seen in the Aurignacian sphere throughout Europe (e.g. ed. Demidenko et al. 2012; ed. Le Brun-Ricalens et al. 2005; Nigst 2012; Sinitsyn 2015; Teyssandier, Liolios 2003). Also, the recurrence of occupations in MMG suggests a persistent Aurignacian presence in the area. The question of a particularly late occurrence of the Aurignacian relies mostly on the "Aurignacian III Supérieur» horizon. Even though lithic data is a bit ambiguous, the existence of a gap between this horizon and the next Gravettian ones strengthens its association to the previous levels. All this suggests the Aurignacian lasted until approximately $27500 \mathrm{BP}$ on the middle Prut river.

On the Gravettian side, abundant materials from Molodova V/9 allow to define precisely the means and goals of the bladelet production. Cores do not show any convergence of their surfaces laterally or frontally like in the Aurignacian. In fact, raw materials are especially chosen to install a straighter production surface with parallel sides, as reflected on the obtained blanks. Despite its limited status, data from Molodova V/10 corresponds to the same scheme and is irrefutably Gravettian. An Aurignacian interpretation of materials, relying mostly on the presence of a «carinated» endscraper, had already been proposed (Allsworth-Jones 1986; Hoffecker 2011), but should be totally refuted. The last disruptive element lies in the presence of the famous bifacial «point» (Chernysh 1987, p. 28, fig. 15), which is not explained. No bifacial shaping artefacts or related are present in the materials, and this tool should then be assumed as an import on the site. The lack of detailed contextual data does not allow to confirm its strict association to the rest of the assemblage, especially as no other site with clear context and equivalent chronological situation presents the same association of materials. Consequently, it should be considered that the Gravettian in Molodova V appears fully characteristic and independent from the Aurignacian in the bladelet production domain.

Since Haesaerts' geological investigations and Noiret's synthetic works, the MMG and Molodova $\mathrm{V}$ sequences have appeared to be the only ones able to highlight this "transition" phenomenon and build a consistent model. Strict observation of radiocarbon dates suggests that a case of contemporaneity is exceptionally documented, with an Aurignacian presence on the Prut while Gravettian features have already appeared on the Dniestr. However, this unique early Gravettian occurrence is followed by a 2000 years old hiatus before its next observation, making it a very lonely instance. Indeed, a «classic» succession model should not be directly left aside, as the raw technological data from MMG and Molodova V doesn't suggest any clear link between both industries. Facing such fact, validation of a model is only possible after having re-examined contextual data from Molodova $\mathrm{V}$, to confirm the association of materials labelled as levels 10 and 9 with the stratigraphy and dates.

Conclusion.Mitoc-Malu Galben and Molodova V find no analogies in the middle Prut and 
Dniestr area to question the Aurignacian to Gravettian shift. If the succession from one to the other makes no doubt, the modalities are still unknown. The new technological data here acquired highlights the discrepancy or, at least, the lack of clear link in the lithic domain. If this allows to rule out any "transitional» hypotheses, no population dynamics model can be confirmed. Simultaneity and strict succession scenarios both need further information from sites contexts. More especially, association of materials to stratigraphy should be investigated in the Early Gravettian of Molodova V.

Acknowledgment. First thanks go to Ruslan Koropetskyi in Lviv and Cristina Cordoş in Iaşi for both giving me complete access to materials studied and exposed in this paper. An additional greeting is meant for Larissa Koulakovska, for proposing me to participate in this conference, and hence to diffuse those preliminary results among Ukrainian colleagues.

\section{REFERENCES}

Allsworth-Jones, P. 1986. The Szeletian and the Transition from Middle to Upper Palaeolithic in Central Europe. Oxford: Clarendon Press.

Anikovich, M. 1992. Early Upper Paleolithic Industries of Eastern Europe. Journal of World Prehistory, 6, 2, p. 205245.

Bar-Yosef, O., Zilhro, J. (eds.). 2006. Towards a definition of the Aurignacian. Proceedings of the Symposium held in Lisbon, Portugal, June 25-30, 2002. Trabalhos de Arqueologia, 45. Lisboa.

Borziak, I. A., Koulakovska, L. V. 1998. The Gravettian of the Dniestr Area. Synthesis. Arkheologia, p. 55-63 (In Ukrainian).

Chernysh, A. P. 1987. The standard multilayered site Molodova V. In: Ivanova, I. K., Tzeitlin, S. M. (eds.). The Multilayered paleolithic Site Molodova V. The Stone Age Men and Environment. Moscow: Nauka, p. 7-93 (In Russian).

Demidenko, Yu. E., Otte, M., Noiret, P. (eds.). 2012. Siuren I Rock-Shelter. From Late Middle Paleolithic and Early Upper Paleolithic to Epi-Paleolithic in Crimea. Études et Recherches Archéologiques de l'Université de Liège, 129. Liège.

Fu, Q., Posth, C., Hajdinjak, M., Petr, M., Mallick, S., Fernandes, D., Furtwängler, A., Haak, W., Meyer, M., Mittnik, A. et al. 2016. The genetic history of Ice Age Europe. Nature, 534, p. 200-205.

Goutas, N., Klaric, L., Pesesse, D., Guillermin, P. (eds.). 2011. A la recherche des identités gravettiennes: actualités, questionnements et perspectives. Société préhistorique française, Mémoire LII. Aix-en-Provence.

Haesaerts, P. 2007. Mitoc-Malu Galben: Cadre stratigraphique et chronologique. In: Otte, M., Chirica, V., Haesaerts, P. (eds.). L'Aurignacien et le Gravettien de MitocMalu Galben (Moldavie Roumaine). Études et Recherches Archéologiques de l'Université de Liège, 129. Liège, 72. Liège, p. 15-41.

Haesaerts, P., Borziak, I., Chirica, V., Damblon, F., Koulakovska, L., Van Der Plicht, J. 2003. The east Carpathian loess record: A reference for the middle and late pleniglacial stratigraphy in central Europe. Quaternaire, 14, 3, p. 163-188.

Haesaerts, P., Damblon, F., Bachner, M., Trnka, G. 1996. Revised stratigraphy and chronology of the Willendorf II sequence. Archaeologia Austriaca, 80, p. 25-42.

Hoffecker, J. F. 2011. The Early Upper Paleolithic of Eastern Europe Reconsidered. Evolutionary Anthropology, 20, p. 24-39.

Hoffecker, J. F., Holliday, V. T., Stepanchuk, V. N., Lisitsyn, S. N. 2018. The hunting of horse and the problem of the Aurignacian on the central plain of Eastern Europe. Quaternary International, 492, p. 53-63.
Hublin, J.-J. 2015. The modern human colonization of western Eurasia: when and where? Quaternary Science Review, 118, p. 194-210.

Ivanova, I. K. 1987. Paleogeography and Paleoecology of the environment of stone age men inhabitance in the Middle Dniestr. Site of Molodova V. In: Ivanova, I. K., Tzeitlin, S. M. (eds.). The Multilayered paleolithic Site Molodova V. The Stone Age Men and Environment. Moscow: Nauka, p. 94123 (In Russian).

Ivanova, I. K., Tzeitlin, S. M. (eds.). 1987. The Multilayered paleolithic Site Molodova V. The Stone Age Men and Environment. Moscow: Nauka (In Russian).

Kozłowski, J. K. 2015. The origin of the Gravettian. Quaternary International, 359-360, p. 3-18.

Kozłowski, J. K., Otte, M. 2000. The Formation of the Aurignacian. Journal of Anthropological Research, 56, 4, p. 513534.

Le Brun-Ricalens, F. 2005. Chronique d'une reconnaissance attendue. Outils "carénés», outils «nucléiformes»: nucléus a lamelles. Bilan après un siècle de recherches typologiques, technologiques et tracéologiques. In: Le Brun-Ricalens, F., Bordes, J.-G., Bon, F. (eds.). Productions lamellaires attribuées a l'Aurignacien: chaones opératoires et perspectives technoculturelles. Actes du XIVe Congrès de l'UISPP (2-8 septembre 2001). Archéologiques, 1. Luxembourg, p. 23-71.

Le Brun-Ricalens, F., Bordes, J.-G., Bon, F. (eds.). 2005. Productions lamellaires attribuées a l'Aurignacien: chaones opératoires et perspectives technoculturelles. Actes du XIVe Congrès de l'UISPP (2-8 septembre 2001). Archéologiques, 1. Luxembourg.

Libois, T., Nigst, P. R., Haesaerts, P., Bosch, M. D., Murphree, W. C., Branscombe, T., Noiret, P. 2018. 40 ans de recherches avec Vasile Chirica. In: Lazarovici, C. M., Berzovan, A. (eds.). Quaestiones Praehistoricae. Studia in honorem Professoris Vasile Chirica. Honoraria, XIV. Bucureşti; Brăila: Academia Română; Istros, p. 53-74.

Nigst, P. R. 2012. The Early Upper Palaeolithic of the Middle Danube Region. Leiden: Leiden University.

Nigst, P. R., Haesaerts, P., Damblonm, F., Frank-Fellner, Ch., Mallol, C., Viola, B., Götzinger, M., Niven, L., Trnka, G., Hublin, J.-J. 2014. Early modern human settlement of Europe north of the Alps occurred 43,500 years ago in a cold steppetype environment. Proceedings of the NAS, USA, 111, 40, p. $14394-14399$.

Noiret, P. 2004. Le Paléolithique supérieur de la Moldavie. L'anthropologie, 108, p. 425-470.

Noiret, P. 2005. Productions lamellaires aurignaciennes a l'est des Carpathes. In: Le Brun-Ricalens, F., Bordes, J.-G., Bon, F. (eds.). Productions lamellaires attribuées a l'Aurignacien: chaones opératoires et perspectives technoculturelles. Actes du XIV e Congrès de l'UISPP (2-8 septembre 2001). Archéologiques, 1. Luxembourg, p. 439-462.

Noiret, P. 2007. Le Gravettien de Moldavie. Paleo, 19, p. $159-180$

Noiret, P. 2009. Le Paléolithique Supérieur de Moldavie. Essai de synthuse d'une évolution multiculturelle. Études et Recherches Archéologiques de l'Université de Liège, 121. Liège.

Noiret, P., Haesaerts, P., Vornicu, M., Bodi, G., Branscombe, T., Libois, T., Bosch, M., Nigst, P. R. 2016. Nouvelles recherches de terrain a Mitoc-Malu Galben 2013-2015. In: Chirica, V., Ichim, C. (eds.). Les Aurignaciens: leur création matérielle et spirituelle. Actes du Colloque international de Iasi (28-31 janvier 2016). Bibliotheca Archaeologica Iassiensis, XXVII. Târgovişte: Cetatea de Scaun, p. 13-49.

Noiret, P., Zwyns, N., Chirica, V. 2006. Production lamellaire aurignacienne a Mitoc-Malu Galben, Roumanie. In: Acts of $X V^{\text {hh }}$ Congress of UISPP. Unpublished.

Otte, M., Noiret, P. 2004. Évolution du Gravettien au Moyen Danube. In: Svoboda, J., Sedlácková, L. (eds.). The Gravettian along the Danube. Proceedings of the Mikulov Conference, 20-21 November 2002. Dolní Věstonice Studies, 11. Brno: Institute of Archaeology CAS, p. 9-32.

Otte, M., Chirica, V., Haesaerts, P. (eds.). 2007a. L'Aurignacien et le Gravettien de Mitoc-Malu Galben (Moldavie Roumaine). Études et Recherches Archéologiques de l'Université de Liège, 72. Liège.

Otte, M., Noiret, P., Chirica, V., Borziac, I. 2007b. Mitoc Malu-Galben: Étude de l'industrie lithique. In: Otte, M., Chirica, 
V., Haesaerts, P. (eds.). L'Aurignacien et le Gravettien de Mitoc-Malu Galben (Moldavie Roumaine). Études et Recherches Archéologiques de l'Université de Liège, 72. Liège, p. 85-135.

Otte, M. (ed.). 2013. Les Gravettiens. Paris: Errance.

Pesesse, D. 2013. Le Gravettien existe-t-il? Le prisme du systume technique lithique. In: Otte, M. (ed.). Les Gravettiens. Paris: Errance, p. 67-104

Sinitsyn, A. A. 1993. Les niveaux aurignaciens de Kostienki I. In: Actes du XII ${ }^{e}$ Congrès de l'UISPP (Bratislava, 1-7 septembre 1991). Bratislava: Institut Archéologique de SAV, p. 242-259.

Sinitsyn, A. A. 2003. A Palaeolithic «Pompeii» at Kostenki, Russia. Antiquity, 77 (295), p. 9-14.

Sinitsyn, A. A. 2015. Perspectives on the Palaeolithic of Eurasia: Kostenki and related sites. In: Sanz, N. (ed.). Human Origins Sites and the World Heritage Convention in Eurasia. Paris; Mexico City: United Nations Educational; Scientific and Cultural Organization, p. 163-189.

Teyssandier, N., Liolios, D. 2003. Defining the earliest Aurignacian in the Swabian Alp: the relevance of the technological study of the Geissenklцsterle (Baden-Württemberg, Germany) lithic and organic productions. In: Zilhго, J., d'Errico, F. H. (eds.). The Chronology of the Aurignacian and of the Transitional Technocomplexes: Dating, Stratigraphies, Cultural Implications. Proceedings of Symposium 6.1 of the $X I^{\text {th }}$ Congress of the UISPP (University of Liège, Belgium, September 2-8, 2001). Trabalhos de Arqueologia, 33. Lisboa, p. 179-196.

Zilhro, J., d'Errico, F. H. (eds.). 2003. The Chronology of the Aurignacian and of the Transitional Technocomplexes: Dating, Stratigraphies, Cultural Implications. Proceedings of Symposium 6.1 of the XIV ${ }^{\text {th }}$ Congress of the UISPP (University of Liège, Belgium, September 2-8, 2001). Trabalhos de Arqueologia, 33. Lisboa.

\section{T. Libois}

\section{STUDY OF THE AURIGNACIAN- GRAVETTIAN «TRANSITION» EAST OF THE CARPATHIANS: BLADELET PRODUCTION FEATURES FROM MITOC-MALU GALBEN (ROMANIA) AND MOLODOVA V (UKRAINE)}

In the frame of the Aurignacian to Gravettian "transition", this research aims at highlighting the modalities of this shift in the middle Prut and Dniestr area through the comparison of bladelets production schemes in both cultural entities. Two Late Aurignacian assemblages from Mitoc-Malu Galben (Romania) and relevant materials from Molodova V (Ukraine) were then examined in this perspective. In the case of Mitoc-Malu Galben, qualitative preliminary results underline the consistence and continuity of production from "Aurignacian I» to «III» levels, which aims for twisted naturally blanks produced from convergent shaped knapping surfaces. Less documented, the "Aurignacian III Supérieur» level seems to follow, despite some potential slight discrepancies. In Molodova V, cultural horizons 10 and 9 apply to a different consistent pattern, as cores are shaped and exploited to produce straighter blanks with parallel sides. Those technological insights reaffirm the independent identity of the local Gravettian in comparison to the Aurignacian. Based only on the large set of radiocarbon dates available for both sites, a simultaneity model arises, in slight contradiction with the technological data. Then, a «classic» succession model should not be left aside.
Re-investigation of contextual data, including association of materials to dates, is needed to confirm any population dynamics model.

Keywords: Bladelet production, Lithic technology, Aurignacian, Gravettian, Eastern Europe.

\section{T. Лібуа}

\section{ДОСЛІДЖЕННЯ ОРІНЬЯКО-ГРАВЕТ- СЬКОГО «ПЕРЕХОДУ» В СХІДНИХ КАРПАТАХ: ОСОБЛИВОСТІ ВИРОБ- НИЦТВА ВКЛАДЕНІВ СТОЯНОК МІТОК-МАЛУ ГАЛБЕН (РУМУНІЯ) ТА МОЛОДОВА V (УКРАЇНА)}

Метою цього дослідження, що проведене в межах вивчення переходу від оріньяку до гравету, є висвітлення і зіставлення способів виробництва вкладенів в обох культурах в басейнах Середнього Прута і Дністра. 3 ціеї точки зору розглянуто два пізньооріньякські ансамблі 3 Міток-Малу Гальбен (Румунія) й аналогічні матеріали зі стоянки Молодова V (Україна). Попередні результати вивчення матеріалів з Міток-Малу Гальбен демонструють стабільність і безперервність виробництва від рівня «Оріньяк I» до «III», що було спрямоване на природно вигнуті заготовки, виготовлені 3 подібних за формою поверхонь. Попри можливі незначні розбіжності, це ж стосуеться і рівня «Оріньяк III Supérieur», який зафріксований гірше. У Молодова V культурні горизонти 10 і 9 належать до іншого узгодженого шаблону, коли ядра фрормуються i використовуються для отримання більш прямих заготовок з паралельними сторонами. Ці технологічні особливості підтверджують незалежний розвиток місцевого гравету порівняно з оріньяком. Хоча численні радіовуглецеві дати, отримані з обох стоянок, свідчать про їхню одночасність, це дещо суперечить технологічним даним. Відтак не слід залишати осторонь "класичну» модель наступності. Для підтвердження будь-якої моделі динаміки популяції необхідне повторне дослідження контекстних даних включно 3 прив'язкою матеріалів до дат.

Ключові слова: виробництво вкладенів, кам'яна індустрія, оріньяк, гравет, Східна Свропа.

Одержано 15.04.2020

ЛІБУА Тімоте, докторант, стипендіат Фонду наукових досліджень, Льєжський університет, набережна Рузвельта, 1В (буд. А4), Льєж, 4000, Бельгія.

LIBOIS Timothée, PhD student, FNRS research fellow, Université de Liège, Quai Roosevelt, 1B (Bat. A4), Liège, 4000, Belgium.

ORCID: 0000-0001-7701-8282,e-mail: timothee.libois@ gmail.com. 